\title{
Cyclic mechanical stretch down-regulates cathelicidin antimicrobial peptide expression and activates a pro- inflammatory response in human bronchial epithelial cells.
}

Harpa Karadottir, Nikhil Nitin Kulkarni, Thorarinn Gudjonsson, Sigurbergur Karason, Gudmundur Hrafn Gudmundsson

Mechanical ventilation (MV) of patients can cause damage to bronchoalveolar epithelium, leading to a sterile inflammatory response, infection and in severe cases sepsis. Limited knowledge is available on the effects of MV on the innate immune defense system in the human lung. In this study, we demonstrate that cyclic stretch of the human bronchial epithelial cell lines VA10 and BCi NS 1.1 leads to down-regulation of cathelicidin antimicrobial peptide (CAMP) gene expression. We show that treatment of VA10 cells with vitamin D3 and/or 4-phenyl butyric acid counteracted cyclic stretch mediated downregulation of CAMP mRNA and protein expression (LL-37). Further, we observed an increase in pro-inflammatory responses in the VA10 cell line subjected to cyclic stretch. The mRNA expression of the genes encoding pro-inflammatory cytokines IL- 8 and IL-1 $\beta$ was increased after cyclic stretching, where as a decrease in gene expression of chemokines IP-10 and RANTES was observed. Cyclic stretch enhanced oxidative stress in the VA10 cells. The mRNA expression of toll-like receptor (TLR) 3, TLR5 and TLR8 was reduced, while the gene expression of TLR2 was increased in VA10 cells after cyclic stretch. In conclusion, our in vitro results indicate that cyclic stretch may differentially modulate innate immunity by down-regulation of antimicrobial peptide expression and increase in pro-inflammatory responses. 


\section{Cyclic mechanical stretch down-regulates cathelicidin antimicrobial}

2 peptide expression and activates a pro-inflammatory response in

3 human bronchial epithelial cells.

4

5 Harpa Karadottir $^{1 *}$, Nikhil Nitin Kulkarni ${ }^{1 *}$, Thorarin Gudjonsson ${ }^{2,3}$, Sigurbergur Karason ${ }^{4}$,

6 Gudmundur Hrafn Gudmundsson" ${ }^{1 \#}$.

$8{ }^{1}$ Biomedical Center and Department of Life and Environmental Sciences, University of Iceland,

9 Reykjavík, Iceland.

$11{ }^{2}$ Stem Cell Research Unit, Biomedical Center, Department of Anatomy, Faculty of Medicine,

12 School of Health Sciences, University of Iceland, Iceland.

${ }^{3}$ Department of Laboratory Hematology, Landspitali-University Hospital, Iceland.

${ }^{4}$ Department of Anaesthesia and Intensive Care, Landspitali University Hospital, Reykjavik,

17 Iceland and Faculty of Medicine, University of Iceland, Reykjavik, Iceland.

*- Equal Contribution.

\#- Corresponding author: Gudmundur H. Gudmundsson, PhD. 


\section{ABSTRACT}

Mechanical ventilation (MV) of patients can cause damage to bronchoalveolar epithelium, leading to a sterile inflammatory response, infection and in severe cases sepsis.

34 Limited knowledge is available on the effects of MV on the innate immune defense system in the 35 human lung. In this study, we demonstrate that cyclic stretch of the human bronchial epithelial cell lines VA10 and BCi NS 1.1 leads to down-regulation of cathelicidin antimicrobial peptide $(C A M P)$ gene expression. We show that treatment of VA10 cells with vitamin D3 and/or 4phenyl butyric acid counteracted cyclic stretch mediated down-regulation of CAMP mRNA and protein expression (LL-37). Further, we observed an increase in pro-inflammatory responses in the VA10 cell line subjected to cyclic stretch. The mRNA expression of the genes encoding proinflammatory cytokines IL-8 and IL-1 $\beta$ was increased after cyclic stretching, where as a decrease in gene expression of chemokines IP-10 and RANTES was observed. Cyclic stretch enhanced oxidative stress in the VA10 cells. The mRNA expression of toll-like receptor (TLR) 3, TLR5 and TLR 8 was reduced, while the gene expression of TLR2 was increased in VA10 cells after cyclic stretch. In conclusion, our in vitro results indicate that cyclic stretch may differentially modulate innate immunity by down-regulation of antimicrobial peptide expression and increase in pro-inflammatory responses. 
62

63

64

65

66

67

68

69

70

\section{INTRODUCTION}

3

Mechanical ventilation (MV) is a lifesaving treatment for patients suffering from severe respiratory failure by alleviating the work of breathing and facilitating alveolar gas exchange (Slutsky \& Ranieri, 2013). MV has, however, been associated with side effects including ventilator induced lung injury (VILI) coupled with injury on lung tissue, stress on epithelial and endothelial barriers, apoptosis, pro-inflammatory responses, increased oxidative stress and secondary infections like nosocomial bacterial pneumonia. This can be followed by sepsis or systemic inflammatory response syndrome and increased mortality (Baudouin, 2001; Uhlig, 2002; Syrkina et al., 2008). Success of treatment with MV requires limitation of VILI and associated side effects (Fan, Villar \& Slutsky, 2013). This can be accomplished by either decreasing mechanical stress produced by MV or by increasing the endurance of lung tissues to such strain. Hence, it has become imperative to study the molecular mechanisms behind VILI in details to improve outcomes in patients treated with MV. Although poorly defined, downregulation of innate immune responses has been proposed to favor bacterial growth and development of ventilator associated pneumonia (VAP) in the lungs of patients during MV (Santos et al., 2005).

Antimicrobial polypeptides (AMPs) constitute an important arm of the innate immune defense in the lungs and are expressed ubiquitously in epithelial cells, neutrophils and monocytes or macrophages (Laube et al., 2006). These cationic polypeptides are categorized into: 1) smaller processed peptides such as cathelicidins and defensins and 2) larger polypeptides like lactoferrin, lysozyme and secretory leukocyte peptidase inhibitor (SLPI) (Laube et al., 2006). LL-37 is the main cathelicidin antimicrobial peptide $(C A M P)$ in humans, encoded by the $C A M P$ gene (Dürr, Sudheendra \& Ramamoorthy, 2006). LL-37 is stored as a pro-form (pro-LL-37) in cells and is activated upon secretion to the mature form LL-37 by specific proteases (Sørensen et al., 2001). LL-37 has direct antimicrobial activity against multiple pathogens and has been demonstrated to exhibit pro- and anti-inflammatory responses, wound healing and angiogenic properties (Cederlund, Gudmundsson \& Agerberth, 2011). Inducers of AMPs like vitamin D3 (1, 25dihydroxy vitamin D3 or 1,25D3) and 4-phenyl butyric acid (PBA) have been shown to increase $C A M P$ gene expression via the vitamin D receptor (VDR) (Gombart, Borregaard \& Koeffler, 2005; Kulkarni et al., 2015a ; Kulkarni et al., 2015b). A recent clinical trial demonstrated that 
93 lower vitamin D3 levels and cathelicidin expression was associated with higher mortality in

94 critically ill patients usually receiving MV (Leaf et al., 2015). The effects of MV on respiratory

95 cells can be modeled in vitro by applying defined cyclic mechanical stretch mimicking the

96 frequency and stretch conditions during MV (Pugin et al., 2008; Wu et al., 2013).

97 In this study, we demonstrate that cyclic mechanical stretch of human bronchial epithelial

98 cells VA10 and BCi down-regulates the expression of antimicrobial peptide cathelicidin.

99 Treatment with AMP inducers vitamin D3 and/or PBA counteracted cyclic stretch mediated

100 down-regulation of cathelicidin expression in VA10 cells. We further demonstrate that cyclic

101 stretching of VA10 cells activated a pro-inflammatory response by enhancing expression of pro-

102 inflammatory cytokines and increasing oxidative stress.

103

104

MATERIALS AND METHODS

105

106

\section{Cell Culture, Reagents and Cyclic Stretch:}

An E6/E7 viral oncogene immortalized human bronchial epithelial cell line VA10 was cultured as described previously (Halldorsson \& Asgrimsson, 2007). Briefly, the cells were maintained in Bronchial/Tracheal Epithelial cell growth medium (Cell Applications, USA) with Penicillin-Streptomycin [(20 U/ml, $20 \mu \mathrm{g} / \mathrm{ml}$, respectively) (Life Technologies, USA)] at $37^{\circ} \mathrm{C}$ and $5 \% \mathrm{CO}_{2}$. BCi. NS 1.1 (henceforth referred to as $\mathrm{BCi}$ ) is a human bronchial epithelial cell line

112 was a kind gift from Dr. Matthew S Walters, Weill Cornell Medical College, New York NY,

113 USA (Walters et al., 2013) and was established by immortalization with retrovirus expressing

114 human telomerase (hTERT). The BCi cells were cultured as described above for VA10 cell line.

115 Equal amount of cells were seeded on each well in a 6 well collagen I coated Bioflex plates

116 (Flexcell International Corporation, Burlington, USA), and grown to approximately 80\%

117 confluence. These plates were then transferred to a base plate of the cell stretching equipment

118 Flexcell FX-5000TM Tension System (Flexcell International Corporation, Burlington, USA) in a

119 humidified incubator at $37^{\circ} \mathrm{C}$ and $5 \% \mathrm{CO}_{2}$. The cells were subjected to cyclic mechanical stretch

120 with the following parameters: A stretching rate of $20 \%$ with a square signal, $0.33 \mathrm{~Hz}$ frequency

121 (20 cycles/minute) and a 1:1 stretch: relaxation ratio, as described previously (Pugin et al., 2008).

122 The cells were stretched for $6 \mathrm{~h}$ and $24 \mathrm{~h}$ as described in the results. Control Bioflex plates were

123 kept in the same incubator under static conditions as non-stretch controls. Vitamin D3 $(1,25 \mathrm{D} 3)$ 
124 and Sodium 4-phenyl butyric acid (PBA) were purchased from Tocris bioscience, UK. Vitamin

125 D3 was reconstituted in $100 \%$ ethanol as per manufacturer's instructions. The final concentration

126 of the solvent was kept at $0.2 \% \mathrm{v} / \mathrm{v}$ and did not affect gene and protein expression of target

127 genes. PBA was reconstituted in ultrapure $\mathrm{H}_{2} \mathrm{O}$.

RNA Isolation and Quantitative Real Time PCR:

Total RNA was isolated with NucleoSpin RNA kit (Macherey-Nagel, Germany) and quantified on a spectrophotometer (Nanodrop, Thermo Specific, USA). One $\mu \mathrm{g}$ of total RNA was reverse transcribed into first strand cDNA for each sample with a RevertAid First strand cDNA synthesis kit (Thermo Scientific, USA) and modified with 100 unit of reverse transcriptase per reaction. Power SYBR ${ }^{\circledR}$ green Universal PCR master mix (Life technologies, USA) was used to quantify the cDNA on a 7500 Real time PCR machine (Life technologies,

136 USA). The reference gene used for all experiments was $U B C$ (Ubiquitin C) and PPIA

137 (Peptidylprolyl Isomerase $\mathrm{A}$ ) and an arithmetic mean of reference gene $\mathrm{Ct}$ values was used.

138 Primers for TLR1 and TLR6 were designed with Pearl primer and used at a final concentration of $139300 \mathrm{nM}$ (Marshall, 2004). All other primers were purchased from Integrated DNA technologies

140 (PrimeTime Predesigned qPCR Assay) and used at a final concentration of $500 \mathrm{nM}$ as per 141 manufacturer's instructions. The qPCR cycling conditions were as follows; (1) Hold stage: $95^{\circ} \mathrm{C}$

142 for $10 \mathrm{~min}$, followed by 40 cycles of (2) De-natured stage: $95^{\circ} \mathrm{C}$ for $15 \mathrm{~s}$ and (3)

143 Annealed/extended stage: $60^{\circ} \mathrm{C}$ for $1 \mathrm{~min}$. The $2^{(-\Delta \Delta \mathrm{CT})}$ Livak method was utilized for calculating 144 fold differences over untreated control (Livak \& Schmittgen, 2001). A detailed list of the primers 145 used in the q-RT-PCR assay is shown in Table 1.

Sodium dodecyl Sulfate-Polyacrylamide gel electrophoresis (SDS-PAGE) and Western Blot Analysis:

Supernatants from treated cells were enriched for proteins on Oasis HLB mini columns

150 (Waters, USA) and lyophilized (Speed Vac, Thermo Scientific, USA). Ten $\mu$ g of total

151 lyophilized protein was loaded on a 4-12\% Bis-Tris gradient SDS gel. Protein loading was

152 checked with total protein stain for polyvinylidene fluoride (PVDF) membrane (Pierce

153 MemCode reversible protein stain, Thermo Scientific, USA). Total cell lysate was prepared by

154 addition of RIPA lysis buffer (Sigma Aldrich, USA) supplemented with 1x Halt protease and 
155 phosphatase inhibitor cocktail (Thermo Scientific, USA). Cells were then washed three times

156 with cold 1x PBS, incubated for $30 \mathrm{~min}$ on ice with RIPA buffer and centrifuged at 10,000 rpm

157 for $5 \mathrm{~min}$ at $4^{\circ} \mathrm{C}$. Supernatants obtained were used for Western blot analysis. The protein content

158 of supernatants was analyzed by utilizing a bio rad protein assay dye reagent based on the

159 Bradford dye binding method (Catalog No. 500-0006, Bio-Rad, USA). SDS-PAGE with

160 subsequent Western blot analysis was performed using the NuPage blotting kit (Life

161 Technologies, USA). Ten $\mu$ g of each sample (cell lysates) was loaded on a 4-12\% Bis-Tris

162 gradient gel and run at $200 \mathrm{~V}$ for $30 \mathrm{~min}$. The proteins were then transferred to a PVDF

163 membrane (Millipore, USA) and blocked with 5\% non-fat skimmed milk in 1x phosphate

164 buffered saline (PBS) with 0.05\% tween (Sigma Aldrich, USA). Antibodies against LL-37 were

165 purchased from Innovagen, Sweden (polyclonal Rabbit, Cat No. PA-LL37-100) and

166 Glyceraldehyde 3-phosphate dehydrogenase $(G A P D H)$ from Santa Cruz Biotechnology, USA

167 (polyclonal Rabbit, Cat No. sc-25778). The primary antibodies were diluted 1:1000 in 1\% non-

168 fat skimmed milk powder (Blotto. Santacruz biotechnologies, USA) in $0.05 \%$ Tween 1x PBS

169 and incubated overnight at $4^{\circ} \mathrm{C}$. Next the membrane was incubated with 1:10.000 Horseradish

170 Peroxidase (HRP)-linked secondary anti- rabbit IgG antibody (Cat No. A0545, Sigma Aldrich,

171 USA) in $0.05 \%$ Tween $1 x$ PBS. The protein bands were visualized by chemiluminescence with

172 Pierce ECLPlus Western blotting substrate (Thermo Scientific, USA) on Image Quant LAS 4000

173 station (GE Healthcare, USA).

174

175 Immunofluorescence:

176 VA10 cells were fixed with 3.5\% paraformaldehyde (Sigma Aldrich, USA) prepared in

177 1x PBS for $15 \mathrm{~min}$. The cells were then washed twice with 1x PBS for 10 minutes at room

178 temperature and blocked in immunofluorescence (IF) buffer (10\% Fetal bovine serum (FBS) and

$1790.3 \%$ triton X-100 in 1x PBS) for 30 minutes. The cells were incubated overnight with LL-37

180 primary antibody (polyclonal Rabbit, Cat No. PA-LL37-100, Innovagen, Sweden) diluted 1:100

181 in the IF buffer, at $4^{\circ} \mathrm{C}$. Following overnight incubation, the cells were washed twice with $1 \mathrm{x}$

182 PBS. Next, the cells were incubated with secondary antibody anti-rabbit IgG Alexa Fluorß 488

183 (Catalog No. A11070) /546 conjugate (Catalog No. A11010) from Life Technologies, USA,

184 1:1000 diluted in the IF buffer, for 1 hour at room temperature. The cells were counterstained

185 with nuclear stain 4, 6-diamidino-2-phenylindole (DAPI) at 1:5000 dilution or $3 \mu \mathrm{M}$ in IF buffer 
186 (Catalog No. D9564, Sigma Aldrich, USA). Finally, the cells were washed twice with 1x PBS

187 and ultrapure $\mathrm{H}_{2} \mathrm{O}$, and mounted in Fluormount-G solution (Southern Biotech, Birmingham, AL)

188 for microscopic analysis. The images were captured on Olympus fluoview Fv1200 confocal

189 microscope at a 20X magnification. Olympus fluoview (FV) 1000 software was used for

190 processing the acquired images.

191

192 Oxidative Stress Measurement:

193 After subjecting VA10 cells to cyclic stretch, CellROX green reagent (Life Technologies,

194 USA) was added to the medium at a final concentration of $5 \mu \mathrm{M}$ for 30 minutes. Next, the cells

195 were washed twice with cold 1x PBS (1000 rpm for $5 \mathrm{~min}$ ) and detached with a 1x Accutase

196 solution (Millipore, USA). Cells were then harvested and suspended in $100 \mu 1$ of MACS buffer.

197 (Miltenyi Biotec, USA) as per manufacturer's instructions. The samples were analyzed in

198 MACSQuant flow cytometer (Miltenyi Biotec, USA), placing the CellROX green reagent signal

199 in FL1. Intact cells were gated in the Forward Scatter/Side Scatter plot to exclude debris. The

200 resulting FL1 data was plotted on a histogram and is represented as \% CellROX positive cells

201 before and after cyclic stretch.

202

203

ELISA:

204

205

206

interleukin 8 (IL-8) and interferon gamma-induced protein 10 (IP-10) assay kit according to

207

manufacturer's instructions (Peprotech, UK). The results are represented from three independent

208

209

Statistical Analysis:

The q-RT PCR and ELISA results are represented as means \pm standard errors of the

211

means (S: E.) from three independent experiments. An unpaired Student's t-test was used to

212 compare two samples. $\mathrm{P}<0.05$ was considered statistically significant. All the statistical analysis

213 for q-RT PCR and ELISA experiments was performed with the Prism 6 software (Graph Pad,

214 USA). The Western blot and immunofluorescence data are represented from at least three

215 independent experiments showing similar results.

216 


\section{RESULTS}

218

219

Cyclic stretch down-regulates the expression of the cathelicidin antimicrobial peptide.

220

We screened for the effect of mechanical stretch on AMP expression. VA10 cells were subjected to stretch for 6 and 24 hours to analyze early and late changes in AMP mRNA expression. The mRNA expression of AMPs cathelicidin (CAMP), human beta defensin-1 $(D E F B 1)$, Lactoferrin ( $L T F)$ and Lysozyme ( $L Y Z)$ was analyzed with quantitative real time PCR (qRT-PCR). The basal mRNA expression of $C A M P$ was decreased at both $6 \mathrm{~h}$ and $24 \mathrm{~h}$ after cell stretching (Fig. 1A). DEFB $1 \mathrm{mRNA}$ expression was reduced at $24 \mathrm{~h}$ after cell stretching but was unaffected after $6 \mathrm{~h}$ (Fig. S1). The basal mRNA expression of $L T F$ and $L Z Y$ was very low (Ct $>$ 32 ) in the VA10 cells and was excluded from this study. The decrease in cathelicidin gene expression was further confirmed at protein level with Western blot (Fig. 1B) and immunofluorescence analysis (Fig. 1C). Western blot analysis of stretched VA10 cells showed a decrease in secreted pro-LL-37 (encoded by the CAMP gene) levels after $24 \mathrm{~h}$ of cyclic stretch (Fig. 1B). Further, immunofluorescence staining of stretched VA10 cells also showed a decrease in LL-37 protein expression at both $6 \mathrm{~h}$ and $24 \mathrm{~h}$ after stretching (Fig. 1C).

\section{Treatment with vitamin D3 and/or 4-phenyl butyric acid (PBA) counteracts stretch} mediated down-regulation of cathelicidin expression.

We and others have demonstrated that treatment with vitamin D3 (1,25D3) and PBA enhances cathelicidin expression (Gombart, Borregaard \& Koeffler, 2005; Kulkarni et al., 2015). VA10 cells were treated with $100 \mathrm{nM}$ 1,25D3 (Fig. 2A), 2 mM PBA (Fig. 2B) or co-treated with $2 \mathrm{mM}$ PBA and $100 \mathrm{nM}$ 1,25D3 (Fig. 2C). These cells were then stretched for either $6 \mathrm{~h}$ or $24 \mathrm{~h}$ and gene expression of $C A M P$ was analyzed with q-RT PCR. Treatment of VA10 cells with 1,25D3 and/or PBA before stretch counteracted stretch mediated down-regulation of CAMP mRNA expression (Fig. 2 A-C). This counteraction was further confirmed at protein level with immunofluorescence (Fig. 2E) and Western blot analysis (Fig. 2F). Immunofluorescence staining of LL-37 confirmed that the 1,25D3 treatment prevented stretch mediated decrease in LL-37 protein expression with both at $6 \mathrm{~h}$ and $24 \mathrm{~h}$ stretch (Fig. 2E). Further, VA10 cells were treated with PBA and 1,25D3 as described above and stretched for $24 \mathrm{~h}$. Protein expression of pro-LL-37 was analyzed with Western blot. Co-treatment with PBA and 1,25D3 predominantly 
248 enhanced pro-LL-37 expression in VA10 cells (Fig. 2F). This enhanced expression was lower in

249 the stretched cells (Fig. 2F). Finally, we verified stretch mediated decrease of CAMP mRNA

250 expression in another human bronchial epithelial cell line BCi. Similar to the VA10 cells, the

251 BCi cells were treated with $100 \mathrm{nM}$ 1,25D3 and stretched for $24 \mathrm{~h}$. The basal mRNA expression

252 of $C A M P$ was reduced with 24 stretch, however was not significantly changed after 6 h. Similar

253 to the results in VA10 cells, treatment with 1,25D3 counteracted stretch mediated down-

254 regulation of CAMP mRNA expression in BCi cells (Fig. 2D). Thus, we demonstrate that

255 treatment with 1,25D3 and PBA counteracted cyclic stretch mediated down-regulation of

256 cathelicidin AMP expression.

257

258

259

\section{Cyclic stretch activates a pro-inflammatory response and modulates toll-like receptor} expression.

Previous studies have demonstrated that VILI and in vitro cyclic stretching of alveolar lung epithelial cells activates a pro-inflammatory response by enhanced secretion of proinflammatory cytokines and chemokines (Vlahakis et al., 1999; Halbertsma et al., 2005). We studied the effect of cyclic stretch on inflammation in VA10 cells by screening for stretch mediated changes in pro-inflammatory cytokines and chemokines expression (Fig. 3 A-F). The VA10 cells were stretched for $6 \mathrm{~h}$ and $24 \mathrm{~h}$. The mRNA expression of pro-inflammatory cytokines $C X C L 8$ (encoding interleukin 8 or IL-8), IL1B (encoding interleukin 1 beta or IL-1 $\beta$ ) and chemokines CXCL10 (encoding interferon gamma induced protein 10 or IP-10), CCL5 (encoding regulated on activation, normal $\mathrm{T}$ cell expressed and secreted or RANTES) was analyzed with q-RT PCR (Fig. 3 A-D) after stretching. The mRNA expression of genes encoding IL-8 and IL-1 $\beta$ was enhanced after $6 \mathrm{~h}$ and $24 \mathrm{~h}$ cyclic stretch (Fig. 3 A-C). Interestingly, mRNA expression of the gene encoding IP-10 was reduced following $6 \mathrm{~h}$ and $24 \mathrm{~h}$ stretch (Fig. 3 A-C). The mRNA expression of gene encoding RANTES was reduced after $24 \mathrm{~h}$ stretching and was not affected after $6 \mathrm{~h}$ stretch (Fig. 3D). Analysis of protein expression with ELISA demonstrated enhanced secretion of IL-8 after 24 h of cell stretching (Fig. 3E), whereas the total secreted levels of IP-10 was reduced (Fig. 3F). Increased oxidative stress through enhanced reactive oxygen species (ROS) has been shown to be involved in activation of a pro-inflammatory response (Mittal et al., 2014). We observed increased oxidative stress following cyclic stretch 
$279 \mu \mathrm{M})$ was added $30 \mathrm{~min}$ before end of cyclic stretching. The cells were then harvested and 280 analyzed in a flow cytometer. A significant increase in percentage of Cell ROX positive cells 281 was observed after stretching, indicating increased oxidative stress (Fig. 3G). Thus, we 282 demonstrate that cyclic stretching activates a pro-inflammatory response in VA10 cells.

Next, we screened for stretch mediated changes in toll-like receptor (TLR) expression in VA10 cells (Fig. 4 A-H). TLRs play an important role in activation of pro-inflammatory responses and have been shown to be modulated by mechanical stretching of cells (Takeda \& Akira, 2005; Shyu et al., 2010). VA10 cells were stretched for $6 \mathrm{~h}$ and $24 \mathrm{~h}$ as described above. The mRNA expression of TLR1, TLR2, TLR3, TLR4, TLR5, TLR6, TLR8 and TLR9 was analyzed with q-RT PCR. The mRNA expression of TLR3, TLR 5 and TLR 8 was reduced $6 \mathrm{~h}$ after stretch (Fig. 4 C, E, and G). Further, the mRNA expression of TLR2 (Fig. 4B) was increased and gene expression of TLR3 (Fig. 4C) and TLR9 (Fig. 4H) was decreased after $24 \mathrm{~h}$ stretch.

291

Treatment with vitamin D3 and PBA differentially affects stretch mediated changes in proinflammatory cytokine IL-8 expression. responses, mainly having anti-inflammatory effect (Hansdottir et al., 2010; Roy et al., 2012). VA10 cells were treated with $20 \mathrm{nM}$ 1,25D3 (Fig. 5A) and $2 \mathrm{mM}$ PBA (Fig. 5B), followed by stretching for $6 \mathrm{~h}$ and $24 \mathrm{~h}$ as shown in figure 5 . The mRNA expression of genes encoding the pro-inflammatory cytokine IL-8 was analyzed with q-RT PCR. Treatment with 1,25D3 and PBA increased basal expression of IL-8 after $6 \mathrm{~h}$ treatment in static cells (Fig. $5 \mathrm{~A}$ and B) Interestingly, treatment with PBA significantly enhanced stretch mediated increase in IL-8 gene expression after $6 \mathrm{~h}$ stretch (Fig. 5B). This enhancement was not observed at $24 \mathrm{~h}$ after stretch (Fig. 5B)

303

\section{DISCUSSION}

305

Mechanical ventilation (MV) is necessary for maintenance of gas exchange and to prevent cardiorespiratory collapse in patients suffering from serious respiratory failure and the more severe condition of acute respiratory distress syndrome (ARDS), but may also result in increased mortality of patients by ventilator induced lung injury (VILI) (Slutsky \& Ranieri, 
310 2013). Cyclic stretch generated during MV has been implicated in modulation of innate immune

311 responses leading to side effects that include biotrauma and secondary infections like pneumonia

312 (Santos et al., 2005). We hypothesized that cyclic stretch modulates the expression of

313 antimicrobial peptides (AMPs) that constitute and important arm of the innate immune system.

314 MV can be modelled in vitro by cyclic mechanical stretching of respiratory epithelial cells

315 (Vlahakis et al., 1999; Pugin et al., 2008). In this study we show that cyclic mechanical stretch of

316 human bronchial respiratory epithelial cell line VA10 down-regulates gene expression of AMP

317 cathelicidin and human beta defensin 1 (Fig. 1 and S1). To our knowledge this is first report

318 demonstrating direct effects of mechanical stretch on AMP expression in vitro. AMPs prevent

319 the invasion of pathogens through the lung epithelium and an impaired AMP production could

320 render the tissues more susceptible to infections (Bals et al., 1998). In immunocompromised

321 mice, CRAMP (homologue of human cathelicidin) knockout resulted in increased susceptibility

322 to dermal and respiratory infections (Nizet et al., 2001; Kovach et al., 2012). Our group has

323 previously demonstrated that the diarrhoeal pathogen Shigella down-regulates cathelicidin

324 antimicrobial peptide (CAMP) expression as a strategy to subvert innate immune responses

325 (Islam et al., 2001). This down-regulation can be counteracted by treatment with inducers of

326 cathelicidin like butyric acid and PBA (Raqib et al., 2006; Sarker et al., 2011). In this study, we

327 demonstrate that treatment with vitamin D3 $(1,25 \mathrm{D} 3)$ and PBA counteracts cyclic stretch

328 mediated down-regulation of cathelicidin expression in the VA10 cells (Fig. 2). Interestingly,

329 patients with low vitamin D3 levels admitted to intensive care units receiving MV had higher

330 mortality rate and longer hospital stay than patients with sufficient vitamin D3 (Parekh, Thickett

331 \& Turner, 2013; Leaf et al., 2015; Quraishi et al., 2015). Further, in animal models, MV has been

332 shown to promote bacterial dissemination and infections (Schortgen et al., 2004). Thus induction

333 of AMPs with inducers like 1,25D3 and PBA may be a useful strategy to reduce these

334 complications arising from MV, preventing infections and hence can be sought as adjunct

335 therapeutics.

336 We further studied the effects of cyclic stretch on inflammatory responses in the VA10

337 cells. Lung injury in MV patients is aggravated due to activation of MV mediated sterile

338 inflammatory response and may lead to biotrauma (Santos et al., 2005; Dhanireddy et al., 2006).

339 This damage due to MV activated inflammatory responses is further enhanced during infections.

340 A recent meeting abstract noted that rhinovirus infection enhanced cyclic stretch mediated up- 
341 regulation of pro-inflammatory cytokine expression in human bronchial epithelial cells

342 (Nikitenko et al., 2014). We noticed a significant increase in mRNA expression of genes

343 encoding the pro-inflammatory cytokines IL-8 and IL-1 $\beta$ in the VA10 cells subjected to cyclic

344 stretch (Fig. 3). Interestingly, the gene expression of chemokine IP-10 reduced at both 6 and $24 \mathrm{~h}$

345 of stretch. Further the mRNA expression of chemokine RANTES was down-regulated after $24 \mathrm{~h}$

346 of stretch (Fig. 3). Others have similarly shown cyclic stretch mediated up-regulation of IL-8 and

347 down-regulation of RANTES expression in BEAS-2B human bronchial epithelial cell line

348 (Oudin \& Pugin, 2002; Thomas et al., 2006). Stretch mediated increase in IL-8 levels was shown

349 to be dependent on activation of mitogen activated protein kinase (MAPK) and rho-kinase

350 signaling (Oudin \& Pugin, 2002; Thomas et al., 2006). Further, secretion of IL-1 $\beta$ was shown to

351 be enhanced in mouse alveolar macrophages following MV induced cyclic stretch via caspase-1

352 and TLR 4 dependent activation of NLRP3 inflammasomes (Wu et al., 2013).

353 Increased oxidative stress following cyclic stretch further confirmed activation of a pro-

354 inflammatory response in the VA10 cells (Fig. 3). Recently, cyclic stretch was shown to activate

355 mitochondrial reactive oxygen species (ROS) production via activation of nuclear transcription

356 factor NFKB and NADPH oxidase (Nox) 4 signaling in pulmonary arterial smooth muscle cells

357 (Wedgwood et al., 2015). Mitochondrial ROS drives production of pro-inflammatory cytokines

358 (Naik \& Dixit, 2011). We stained VA10 cells with the CellROX (ROS detector) dye and noticed

359 a significant increase in percentage of CellROX positive VA10 cells after cyclic stretch,

360 indicating enhancement of oxidative stress (Fig. 3). We further looked at the effects of cyclic

361 stretch on expression of toll-like receptors (TLRs). TLRs sense pathogen associated molecular

362 patterns (PAMPs) upon infection, leading to activation of down-stream signaling pathways and

363 induction of pro-inflammatory cytokines and chemokines (Takeda \& Akira, 2005). Cyclic stretch

364 of cultured cardiomyocytes was shown to enhance TLR4 gene expression via activation of the

365 p38 MAPK and NF-кB pathway (Shyu et al., 2010). Interestingly, cyclic stretch of human

366 alveolar epithelial cell line A549 enhanced TLR2 expression (Charles et al., 2011). Further it

367 was demonstrated that cyclic stretch enhanced IL-6 and IL-8 secretion in response to Pam ${ }_{3} \mathrm{CSK}_{4}$,

368 a classical TLR2 ligand (Charles et al., 2011). In our study, the mRNA expression of TLR3,

369 TLR5, TLR8 and TLR9 was down-regulated after cyclic stretch, whereas the gene expression of

370 TLR2 was increased in the VA10 cells (Fig. 4). A direct causal link between the stretch mediated

371 changes in TLR gene expression and pro-inflammatory cytokine expression needs to be 
372 established. Vitamin D3 and PBA have been shown to have anti-inflammatory effects

373 (Hansdottir et al., 2010; Roy et al., 2012). In our study, treatment of the VA10 cells with both

374 1,25D3 and PBA enhanced mRNA expression of the gene encoding IL-8 (Fig. 5). This is in

375 correlation with our previous study in the VA10 cells (Kulkarni et al., 2015). Further, treatment

376 with PBA significantly enhanced stretch mediated increase in IL-8 gene expression $6 \mathrm{~h}$ after

377 stretching in the VA10 cells (Fig. 5).

378 Our study has certain limitations. 1) The study was performed exclusively in cell lines.

379 However, these respiratory cell lines (VA10 and BCi) have been shown to have primary cell like

380 characteristics and have differentiation potential when cultured at an air-liquid interface

381 (Halldorsson et al.; Walters et al., 2013). They represent the upper airway lung epithelia. Primary

382 human bronchial epithelial cells did not grow properly on collagen I coated bioflex silastic

383 membranes and had to be excluded from this study. 2) The mechanism behind cyclic stretch

384 mediated down-regulation of AMP expression needs to be elucidated and is a future area of

385 interest. We hypothesize that stretch activated stress pathways (e.g. hypoxia related HIF-1 $\alpha$

386 (Eckle et al., 2013; Fan et al., 2015)) could be involved in the observed down-regulation of AMP

387 expression. Interestingly, acidification of cellular milieu upon cyclic stretch has been shown to

388 promote bacterial growth in lung epithelial cells (Pugin et al., 2008). The relationship between

389 stretch altered $\mathrm{pH}$ and its effects on AMP gene expression is also an area of interest.

390 In conclusion, our in vitro data shows that cyclic stretch down-regulates the expression of

391 AMP cathelicidin in VA10 and BCi respiratory epithelial cells and activates a pro-inflammatory

392 response in VA10 cells. These results could have clinical implications in regards to ventilator

393 treatment of patients by identifying ways to increase the endurance of lung tissues to mechanical

394 strain and preventing respiratory infections, encouraging further in vivo studies in this field.

395

396 ACKNOWLEDGEMENTS

We would like to thank Jon Thor Bergthorsson and Katrin Birna Petursdottir for the help with analyzing flow cytometry data. We would like to specially thank Arí Jon Arason for introduction to the Flexcell tension system.

400

\section{REFERENCES}


402

403

404

405

406

407

408

409

410

411

412

413

414

415

416

417

418

419

420

421

422

423

424

425

426

427

428

429

430

431

432

433

434

435

Bals R, Wang X, Zasloff M, Wilson JM. 1998. The peptide antibiotic LL-37/hCAP-18 is expressed in epithelia of the human lung where it has broad antimicrobial activity at the airway surface. Proceedings of the National Academy of Sciences of the United States of America 95:9541-6.

Baudouin S V. 2001. Ventilator induced lung injury and infection in the critically ill. Thorax 56:ii50-57.

Cederlund A, Gudmundsson GH, Agerberth B. 2011. Antimicrobial peptides important in innate immunity. The FEBS journal 278:3942-51.

Charles P-E, Tissières P, Barbar SD, Croisier D, Dufour J, Dunn-Siegrist I, Chavanet P, Pugin J. 2011. Mild-stretch mechanical ventilation upregulates toll-like receptor 2 and sensitizes the lung to bacterial lipopeptide. Critical care (London, England) 15:R181.

Dhanireddy S, Altemeier WA, Matute-Bello G, O’Mahony DS, Glenny RW, Martin TR, Liles WC. 2006. Mechanical ventilation induces inflammation, lung injury, and extra-pulmonary organ dysfunction in experimental pneumonia. Laboratory investigation; a journal of technical methods and pathology 86:790-9.

Dürr UHN, Sudheendra US, Ramamoorthy A. 2006. LL-37, the only human member of the cathelicidin family of antimicrobial peptides. Biophysics 1758:1408 - 1425.

Eckle T, Brodsky K, Bonney M, Packard T, Han J, Borchers CH, Mariani TJ, Kominsky DJ, Mittelbronn M, Eltzschig HK. 2013. HIF1A reduces acute lung injury by optimizing carbohydrate metabolism in the alveolar epithelium. PLoS biology 11:e1001665.

Fan D, Coughlin LA, Neubauer MM, Kim J, Kim MS, Zhan X, Simms-Waldrip TR, Xie Y, Hooper L V, Koh AY. 2015. Activation of HIF-1 $\alpha$ and LL-37 by commensal bacteria inhibits Candida albicans colonization. Nature medicine 21:808-814.

Fan E, Villar J, Slutsky AS. 2013. Novel approaches to minimize ventilator-induced lung injury. BMC medicine 11:85.

Gombart AF, Borregaard N, Koeffler HP. 2005. Human cathelicidin antimicrobial peptide (CAMP) gene is a direct target of the vitamin D receptor and is strongly up-regulated in myeloid cells by 1,25-dihydroxyvitamin D3. FASEB journal : official publication of the Federation of American Societies for Experimental Biology 19:1067-77.

Halbertsma FJJ, Vaneker M, Scheffer GJ, van der Hoeven JG. 2005. Cytokines and biotrauma in ventilator-induced lung injury: a critical review of the literature. The Netherlands journal of medicine 63:382-92.

Halldorsson S, Asgrimsson V, Axelsson I, Gudmundsson GH, Steinarsdottir M, Baldursson O, Gudjonsson T. Differentiation potential of a basal epithelial cell line established from 
436

437

438

439

440

441

442

443

444

445

446

447

448

449

450

451

452

453

454

455

456

457

458

459

460

461

462

463

464

465

466 467

human bronchial explant. 2007. In vitro cellular \& developmental biology. Animal 43:2839.

Hansdottir S, Monick MM, Lovan N, Powers L, Gerke A, Hunninghake GW. 2010. Vitamin D decreases respiratory syncytial virus induction of NF-kappaB-linked chemokines and cytokines in airway epithelium while maintaining the antiviral state. Journal of immunology (Baltimore, Md. : 1950) 184:965-74.

Islam D, Bandholtz L, Nilsson J, Wigzell H, Christensson B, Agerberth B, Gudmundsson G. 2001. Downregulation of bactericidal peptides in enteric infections: a novel immune escape mechanism with bacterial DNA as a potential regulator. Nature medicine 7:180-5.

Kovach MA, Ballinger MN, Newstead MW, Zeng X, Bhan U, Yu F, Moore BB, Gallo RL, Standiford TJ. 2012. Cathelicidin-related antimicrobial peptide is required for effective lung mucosal immunity in Gram-negative bacterial pneumonia. Journal of immunology (Baltimore, Md. : 1950) 189:304-11.

Kulkarni NN., Gunnarsson HI., Yi Z., Gudmundsdottir S., Sigurjonsson OE., Agerberth B., Gudmundsson GH. 2015a. Glucocorticoid dexamethasone down-regulates basal and vitamin D3 induced cathelicidin expression in human monocytes and bronchial epithelial cell line. Immunobiology.

Kulkarni NN, Yi Z, Huehnken C, Agerberth B, Gudmundsson GH. 2015b. Phenylbutyrate induces cathelicidin expression via the vitamin D receptor: Linkage to inflammatory and growth factor cytokines pathways. Molecular immunology 63:530-9.

Laube DM, Yim S, Ryan LK, Kisich KO, Diamond G. 2006. Antimicrobial peptides in the airway. Current topics in microbiology and immunology 306:153-82.

Leaf DE, Croy HE, Abrahams SJ, Raed A, Waikar SS. 2015. Cathelicidin antimicrobial protein, vitamin D, and risk of death in critically ill patients. Critical care (London, England) 19:80.

Livak KJ, Schmittgen TD. 2001. Analysis of Relative Gene Expression Data Using Real- Time Quantitative PCR and the 2 (- Delta Delta C (T)) Method. Gene Expression 408:402-408.

Marshall OJ. 2004. PerlPrimer: cross-platform, graphical primer design for standard, bisulphite and real-time PCR. Bioinformatics (Oxford, England) 20:2471-2.

Mittal M, Siddiqui MR, Tran K, Reddy SP, Malik AB. 2014. Reactive oxygen species in inflammation and tissue injury. Antioxidants \& redox signaling 20:1126-67.

Naik E, Dixit VM. 2011. Mitochondrial reactive oxygen species drive proinflammatory cytokine production. The Journal of experimental medicine 208:417-20. 
468

469

470

471

472

473

474

475

476

477

478

479

480

481

482

483

484

485

486

487

488

489

490

491

492

493

494

495

496

497

498

499

500

Nikitenko S, Shariff S, Arnason J, Shelfoon C, Kooi C, Proud D, Leigh R. 2014. Cyclic stretch augments human rhinovirus induced inflammatory responses in airway epithelial cells. Allergy, Asthma \& Clinical Immunology 10:A71.

Nizet V, Ohtake T, Lauth X, Trowbridge J, Rudisill J, Dorschner RA, Pestonjamasp V, Piraino J, Huttner K, Gallo RL. 2001. Innate antimicrobial peptide protects the skin from invasive bacterial infection. Nature 414:454-7.

Oudin S, Pugin J. 2002. Role of MAP kinase activation in interleukin-8 production by human BEAS-2B bronchial epithelial cells submitted to cyclic stretch. American journal of respiratory cell and molecular biology 27:107-14.

Parekh D, Thickett DR, Turner AM. 2013. Vitamin D deficiency and acute lung injury. Inflammation \& allergy drug targets 12:253-61.

Pugin J, Dunn-Siegrist I, Dufour J, Tissières P, Charles P-E, Comte R. 2008. Cyclic stretch of human lung cells induces an acidification and promotes bacterial growth. American journal of respiratory cell and molecular biology 38:362-70.

Quraishi SA, McCarthy C, Blum L, Cobb JP, Camargo CA. 2015. Plasma 25-Hydroxyvitamin D Levels at Initiation of Care and Duration of Mechanical Ventilation in Critically Ill Surgical Patients. JPEN. Journal of parenteral and enteral nutrition.

Raqib R, Sarker P, Bergman P, Ara G, Lindh M, Sack DA, Nasirul Islam KM, Gudmundsson GH, Andersson J, Agerberth B. 2006. Improved outcome in shigellosis associated with butyrate induction of an endogenous peptide antibiotic. Proceedings of the National Academy of Sciences of the United States of America 103:9178-83.

Roy A, Ghosh A, Jana A, Liu X, Brahmachari S, Gendelman HE, Pahan K. 2012. Sodium phenylbutyrate controls neuroinflammatory and antioxidant activities and protects dopaminergic neurons in mouse models of Parkinson's disease. PloS one 7:e38113.

Santos CC dos, Zhang H, Liu M, Slutsky AS. 2005. Bench-to-bedside review: Biotrauma and modulation of the innate immune response. Critical care (London, England) 9:280-6.

Sarker P, Ahmed S, Tiash S, Rekha RS, Stromberg R, Bergman P, Gudmundsson GH, Agerberth B, Raqib R. 2011. Phenylbutyrate Counteracts Shigella Mediated Downregulation of Cathelicidin in Rabbit Lung and Intestinal Epithelia : A Potential Therapeutic Strategy. PloS one 6:e20637.

Schortgen F, Bouadma L, Joly-Guillou M-L, Ricard J-D, Dreyfuss D, Saumon G. 2004. Infectious and inflammatory dissemination are affected by ventilation strategy in rats with unilateral pneumonia. Intensive care medicine 30:693-701. 
501 Shyu K-G, Wang B-W, Lin C-M, Chang H. 2010. Cyclic stretch enhances the expression of toll-

502

503

504

505

506

507

508

509

510

511

512

513

514

515

516

517 like receptor 4 gene in cultured cardiomyocytes via p38 MAP kinase and NF-kappaB pathway. Journal of biomedical science 17:15.

Slutsky AS, Ranieri VM. 2013. Ventilator-induced lung injury. The New England journal of medicine 369:2126-36.

Sørensen OE, Follin P, Johnsen AH, Calafat J, Tjabringa GS, Hiemstra PS, Borregaard N. 2001. Human cathelicidin, hCAP-18, is processed to the antimicrobial peptide LL-37 by extracellular cleavage with proteinase 3. Blood 97:3951-9.

Syrkina O, Jafari B, Hales CA, Quinn DA. 2008. Oxidant stress mediates inflammation and apoptosis in ventilator-induced lung injury. Respirology (Carlton, Vic.) 13:333-40.

Takeda K, Akira S. 2005. Toll-like receptors in innate immunity. International immunology $17: 1-14$.

Thomas RA, Norman JC, Huynh TT, Williams B, Bolton SJ, Wardlaw AJ. 2006. Mechanical stretch has contrasting effects on mediator release from bronchial epithelial cells, with a rho-kinase-dependent component to the mechanotransduction pathway. Respiratory medicine 100:1588-97.

Uhlig S. 2002. Ventilation-induced lung injury and mechanotransduction: stretching it too far? American journal of physiology. Lung cellular and molecular physiology 282:L892-6.

Vlahakis NE, Schroeder MA, Limper AH, Hubmayr RD. 1999. Stretch induces cytokine release by alveolar epithelial cells in vitro. The American journal of physiology 277:L167-73.

Walters MS, Gomi K, Ashbridge B, Moore MAS, Arbelaez V, Heldrich J, Ding B-S, Rafii S, Staudt MR, Crystal RG. 2013. Generation of a human airway epithelium derived basal cell line with multipotent differentiation capacity. Respiratory research 14:135.

Wedgwood S, Lakshminrusimha S, Schumacker PT, Steinhorn RH. 2015. Cyclic stretch stimulates mitochondrial reactive oxygen species and Nox 4 signaling in pulmonary artery smooth muscle cells. American journal of physiology. Lung cellular and molecular physiology 309:L196-203.

Wu J, Yan Z, Schwartz DE, Yu J, Malik AB, Hu G. 2013. Activation of NLRP3 inflammasome in alveolar macrophages contributes to mechanical stretch-induced lung inflammation and injury. Journal of immunology (Baltimore, Md. : 1950) 190:3590-9. 


\section{1}

Figure 1: Cyclic mechanical stretch down-regulates cathelicidin antimicrobial peptide expression.

(A) VA10 cells were stretched for 6 and $24 \mathrm{~h}$. The mRNA expression of cathelicidin antimicrobial peptide (CAMP) was analyzed with q-RT PCR after cell stretching $(n=3$, mean \pm S.E.). Relative expression levels ( $y$-axis) in static cells were defined with an arbitrary value of ' 1 ' and changes relative to this value in stretched samples are represented. (B) VA10 cells were subjected to cyclic stretch for $24 \mathrm{~h}$. Cultured supernatants from stretched cells were used for analysis of secreted cathelicidin (pro-LL-37) protein expression by Western blot. Total protein loading is shown by staining with MemCode blue protein stain. The Western blot is a representative of three independent experiments showing similar results. (C) VA10 cells were stretched for $6 \mathrm{~h}$ and $24 \mathrm{~h}$. The cells were then stained with antibody against LL-37 (green) and protein expression was visualized with immunofluorescence confocal microscopy. The cells were counterstained with nuclear stain DAPI (blue). Data is representative of three independent experiments showing similar results. Bar $=40 \mu \mathrm{m}$. (ns indicates non-significant; $p<0.01=* * ; p<0.001=* * *)$. 
A.

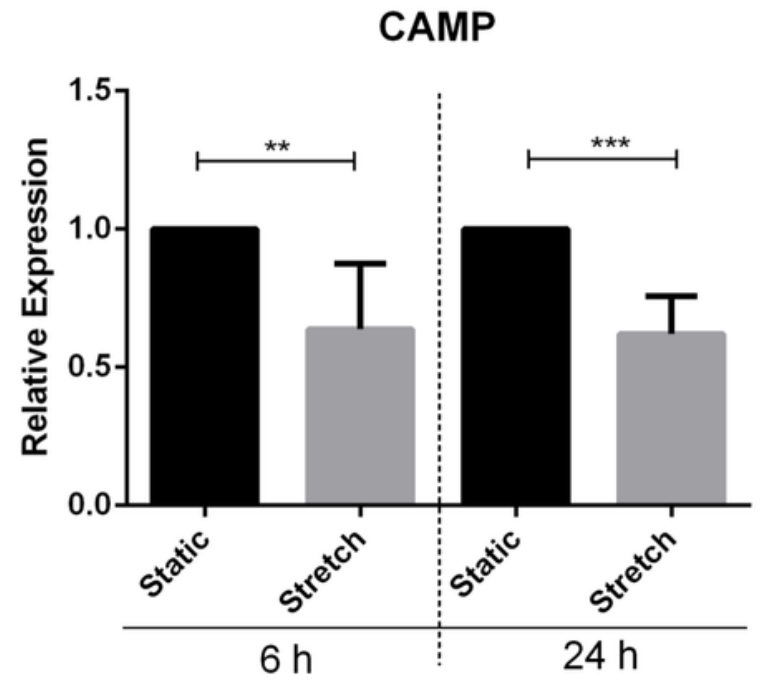

C.

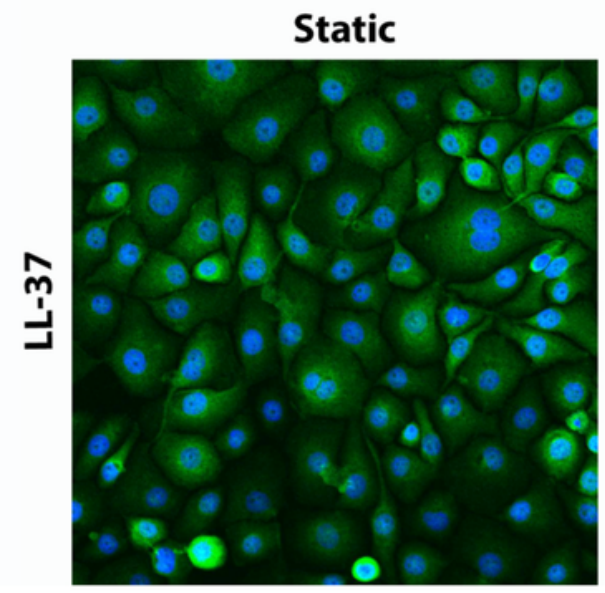

B.

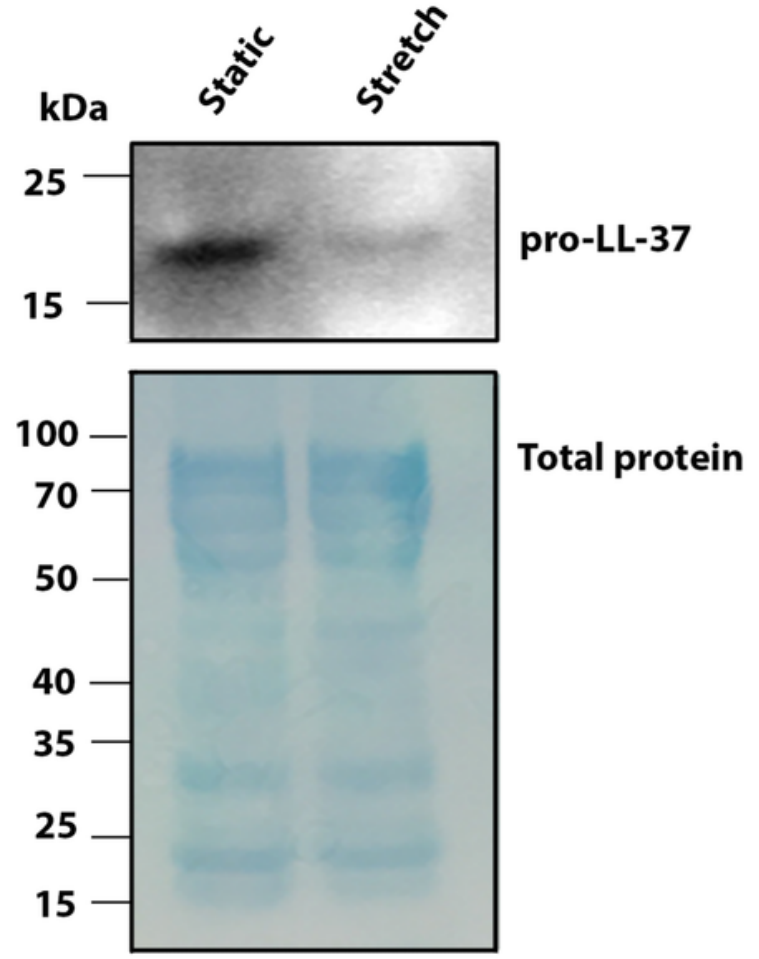

$6 \mathrm{~h}$ stretch

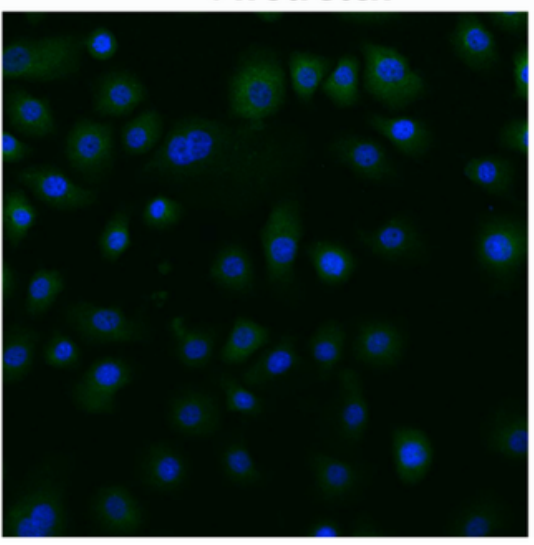

24 h stretch

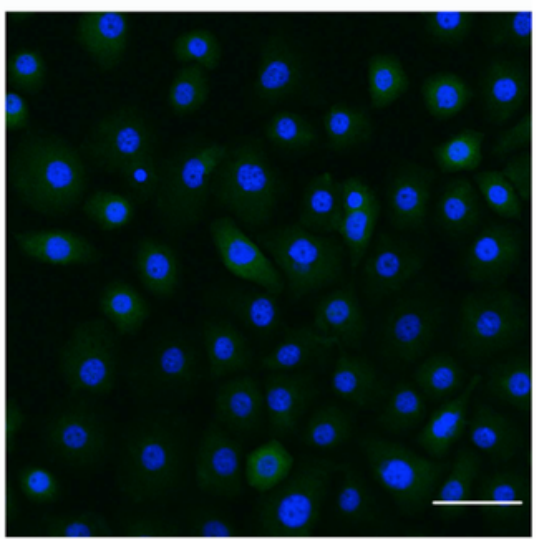


2

Figure 2: Treatment with vitamin D3 (1,25D3) and 4-phenyl butyric acid (PBA) counteracts stretch mediated down-regulation of cathelicidin expression.

(A) VA10 cells were stretched for 6 and $24 \mathrm{~h}$ with (+) or without (-) $100 \mathrm{nM} \mathrm{1,25D3,} \mathrm{(B)} 2 \mathrm{mM}$ PBA and (C) co-treated with vitamin D3 and PBA as shown in the figure. The mRNA expression of CAMP was assessed with qRT-PCR ( $n=3$, mean \pm S.E.). Relative expression levels ( $y$-axis) in static cells were defined with an arbitrary value of ' 1 ' and changes relative to this value in stretched/treated samples are represented. (D) Similarly, the BCi cells were stretched for $6 \mathrm{~h}$ and $24 \mathrm{~h}$ with (+) / without (-) $100 \mathrm{nM}$ 1,25D3 and the mRNA expression of CAMP was analyzed with q-RT PCR $(n=3$, mean \pm S.E.). Relative expression levels ( $y$-axis) in static cells were defined with an arbitrary value of ' 1 ' and changes relative to this value in stretched/treated samples are represented. (E) VA10 cells were treated with $20 \mathrm{nM} \mathrm{1,25D3}$ and stretched for $6 \mathrm{~h}$ and $24 \mathrm{~h}$. LL-37 protein expression (red) was analyzed with immunofluorescence confocal microscopy. The cells were counterstained with nuclear stain DAPI (blue). The data is a representative of three independent experiments showing similar results. Bar $=100 \mu \mathrm{m}$. (F) Protein expression of cellular pro-LL-37 from stretched cells was also analyzed by Western blot analysis. VA10 cells were treated with 2mM PBA, $20 \mathrm{nM}$ 1,25D3 or co-treated with PBA and 1,25D3, followed by stretching for $24 \mathrm{~h}$. GAPDH was used as a loading control. The Western blot is a representative of three independent experiments showing similar results. (ns indicates non-significant; $p<0.05=* ; p<0.01=* * ; p<0.001=* * *$; $\mathrm{p}<0.0001=* * * *)$. 
A.

C.
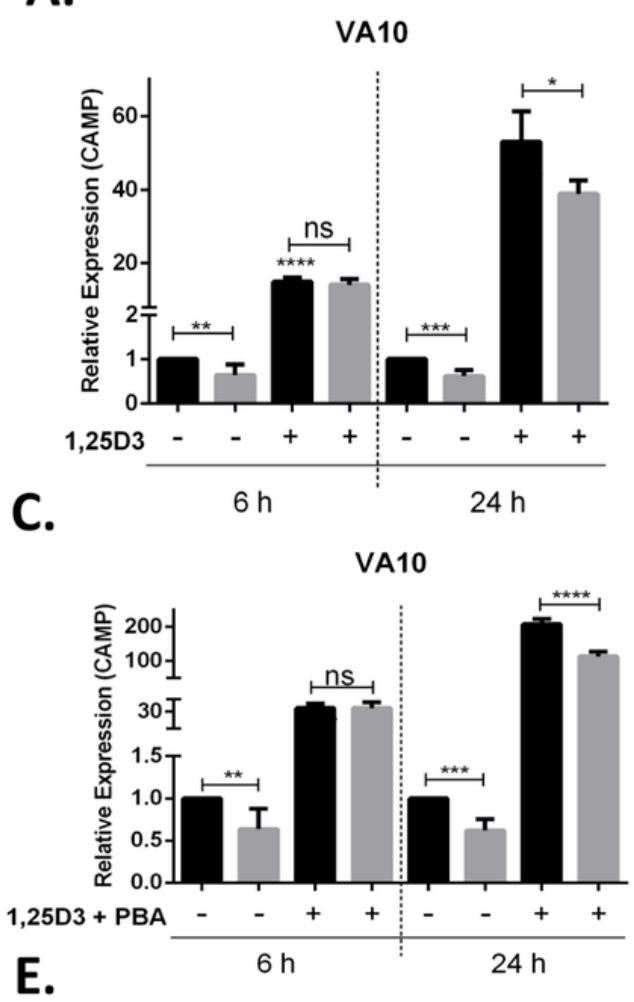

Static
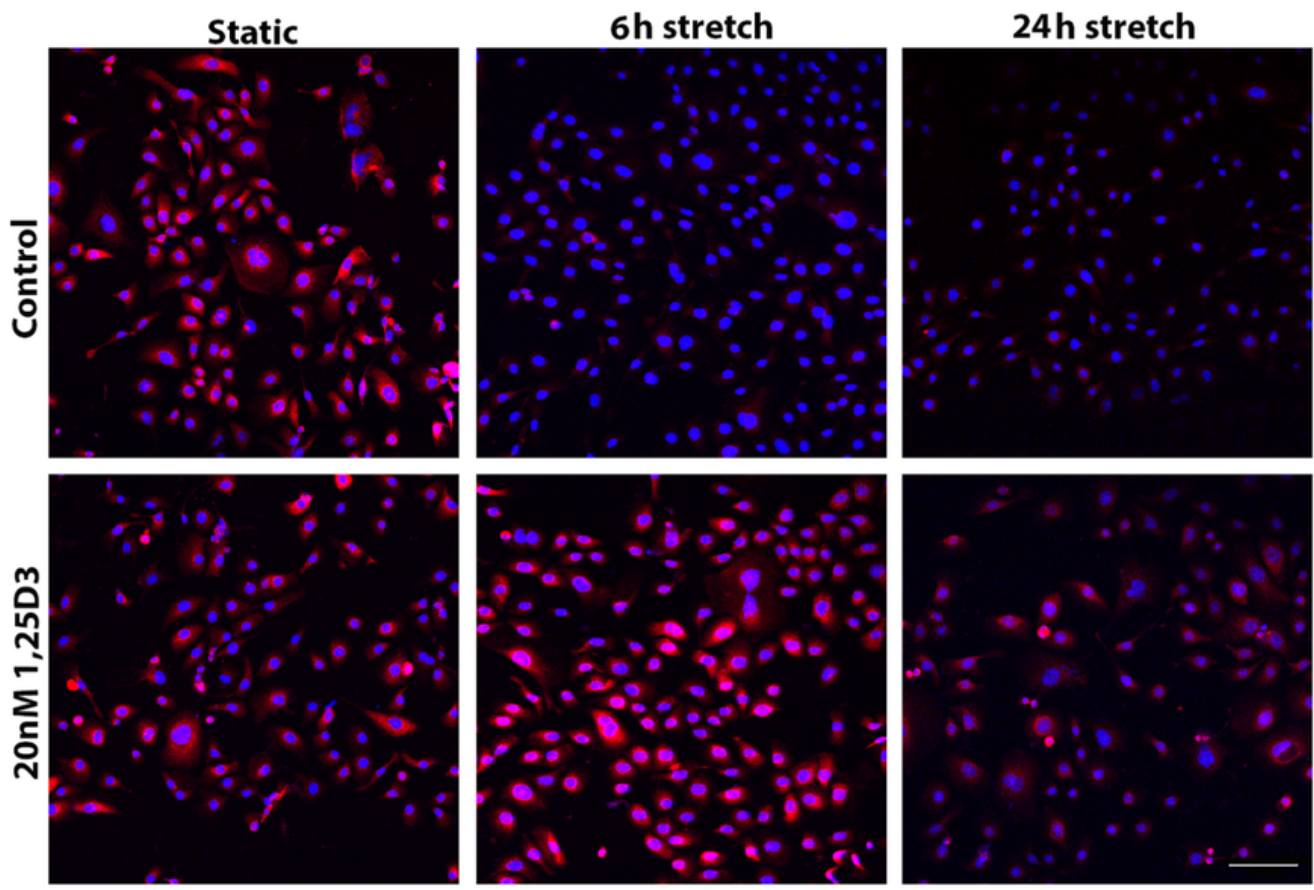

F.

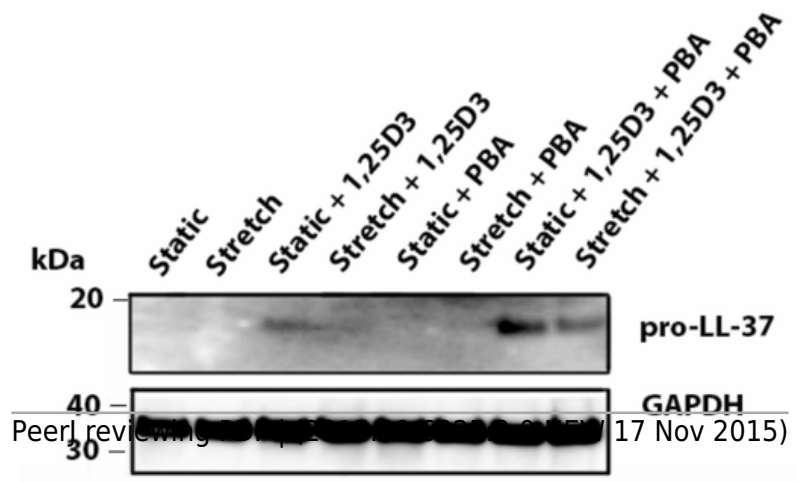

B.

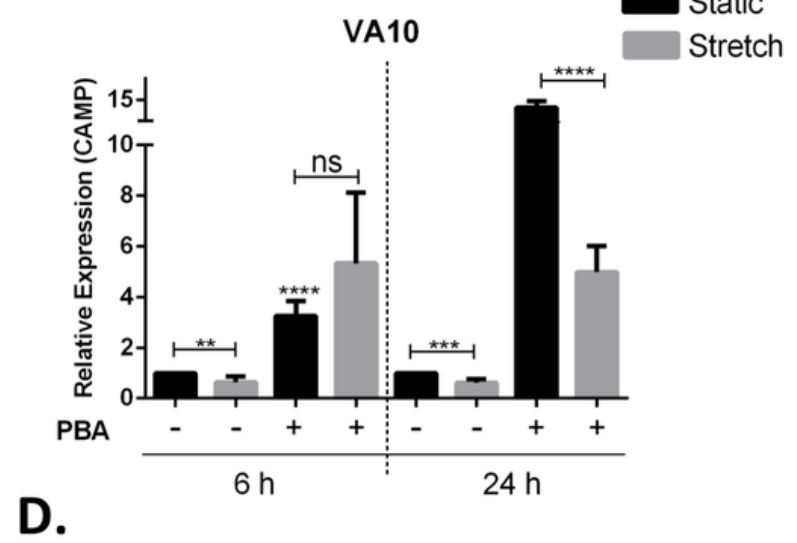

BCi NS1.1

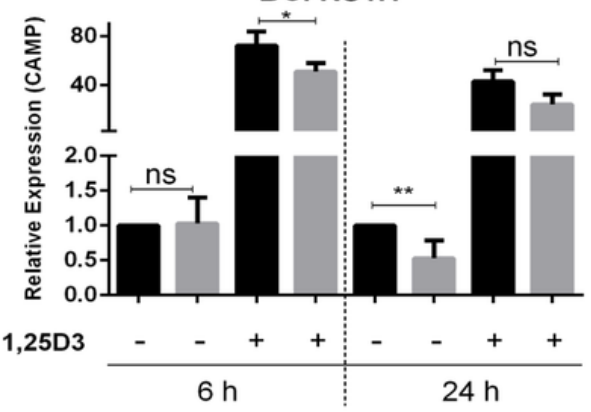

24h stretch

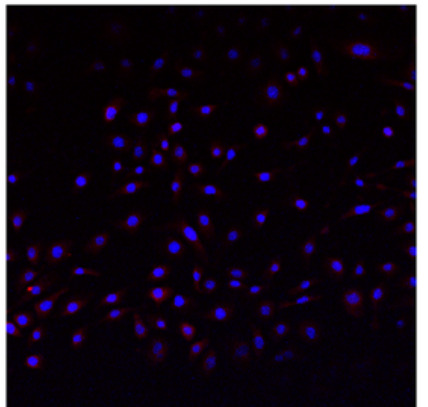




\section{3}

Figure 3: Cyclic stretch activates a pro-inflammatory response and enhances oxidative stress.

(A-D) VA10 cells were subjected to stretch for 6 and 24 hours. The mRNA expression of genes encoding pro inflammatory cytokines IL-8 (A), IL-1ß (B) and chemokines IP-10 (C), RANTES (D) was measured with q-RT PCR ( $n=3$, mean \pm S.E.). Relative expression levels ( $y$ axis) in static cells were defined with an arbitrary value of ' 1 ' and changes relative to this value in stretched samples are represented. (E-F) The protein expression of IL-8 (E) and IP10 (F) from cultured supernatants was measured with ELISA. VA10 cells were stretched for $24 \mathrm{~h}$ and ELISAs were performed ( $\mathrm{n}=3$, mean \pm S.E.). (G) Oxidative stress was measured with CellROX green reagent. VA10 cells were subjected to stretch for $24 \mathrm{~h}$. CellROX dye ( 5 $\mu \mathrm{M})$ was added $30 \mathrm{~min}$ before the end of stretching. The cells were then harvested and analyzed by flow cytometry. The data is represented as percentage positive CellROX (ROS) cells before and after cyclic stretch $(n=3$, mean \pm S.E.). (ns indicates non-significant; $\mathrm{p}<0.05=* ; \mathrm{p}<0.01=* * ; \mathrm{p}<0.001=* * * ; \mathrm{p}<0.0001=* * * *)$. 
A.

c.

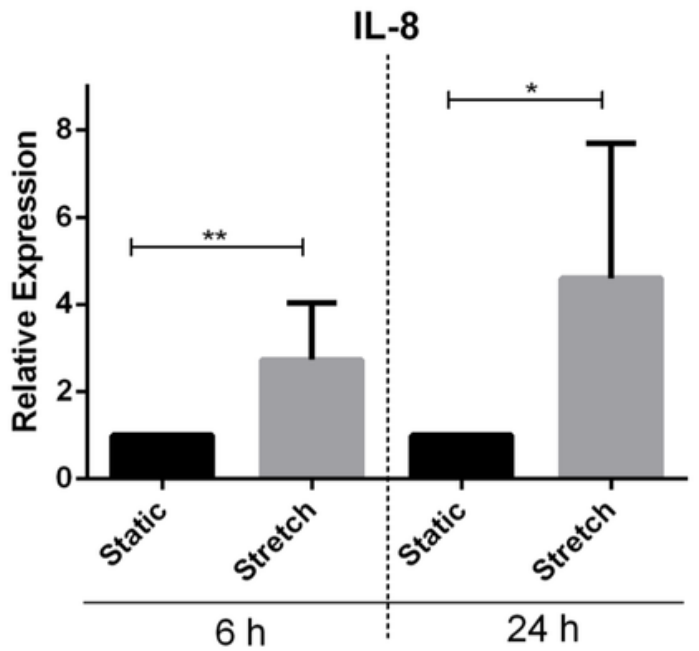

IP-10

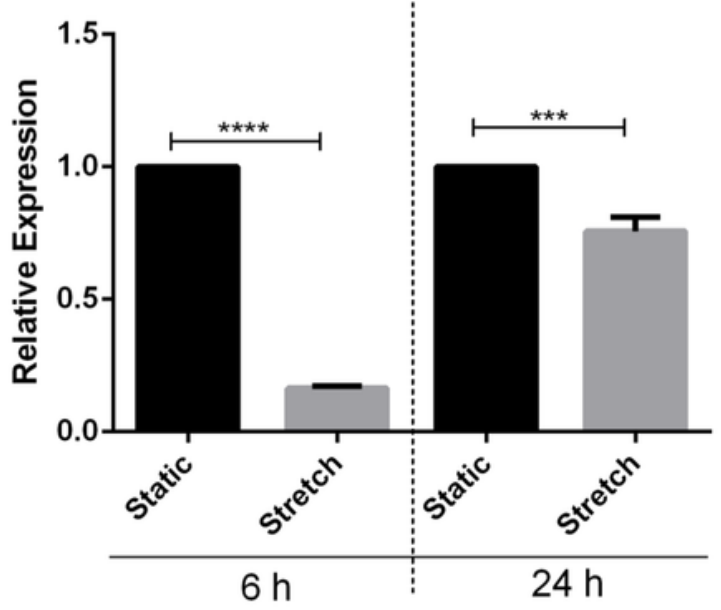

E.

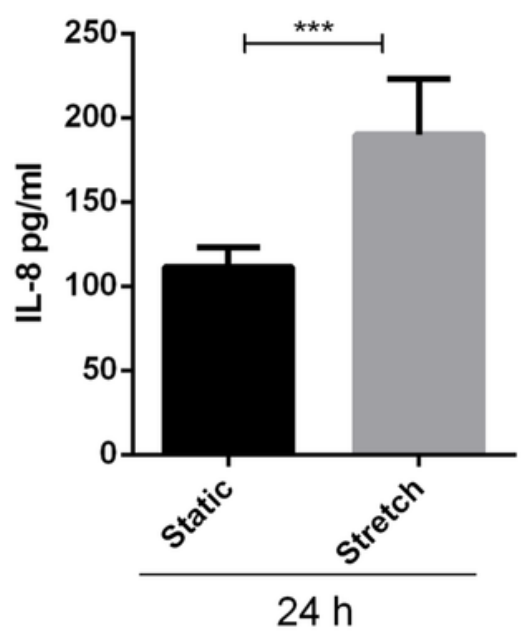

B.
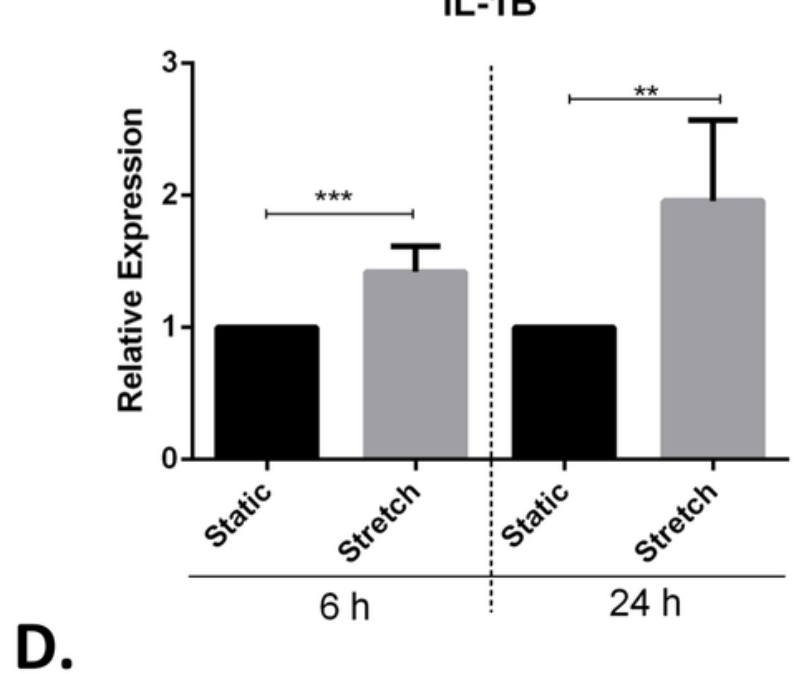

D.

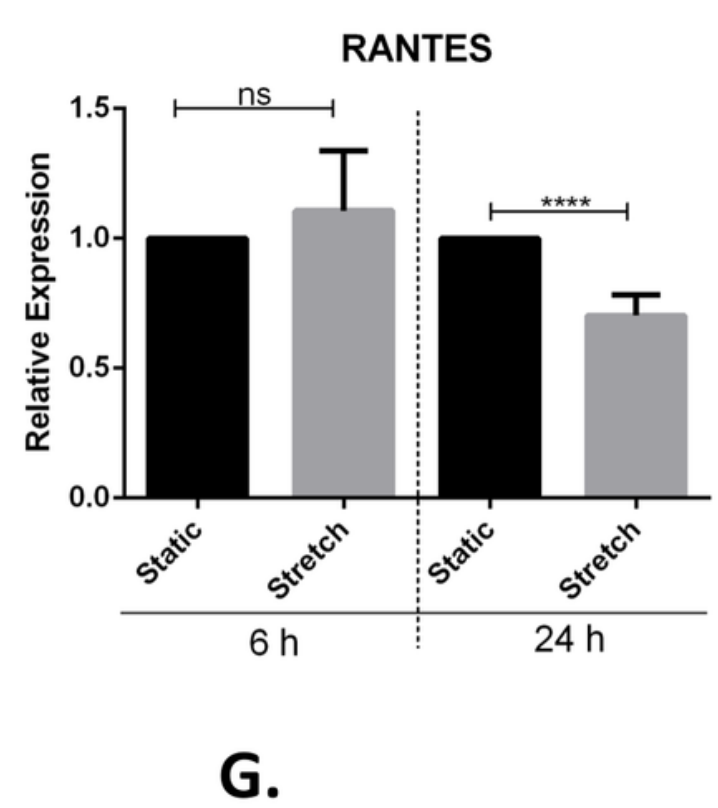




\section{4}

Figure 4: Cyclic stretch modulates toll-like receptor (TLR) gene expression.

(A-H) VA10 cells were subjected to cyclic stretch for $6 \mathrm{~h}$ and $24 \mathrm{~h}$. The mRNA expression of TLR1 (A), TLR2 (B), TLR3 (C), TLR4 (D), TLR5 (E), TLR6 (F), TLR8 (G) and TLR9 (H) was analysed with $\mathrm{q}-\mathrm{RT} P C R(\mathrm{n}=3$, mean \pm S.E.). Relative expression levels ( $y$-axis) in static cells were defined with an arbitrary value of ' 1 ' and changes relative to this value in stretched samples are represented. (ns indicates non-significant; $p<0.05=* ; p<0.01=* * ; p<0.0001=$ $* * * *)$. 
A.

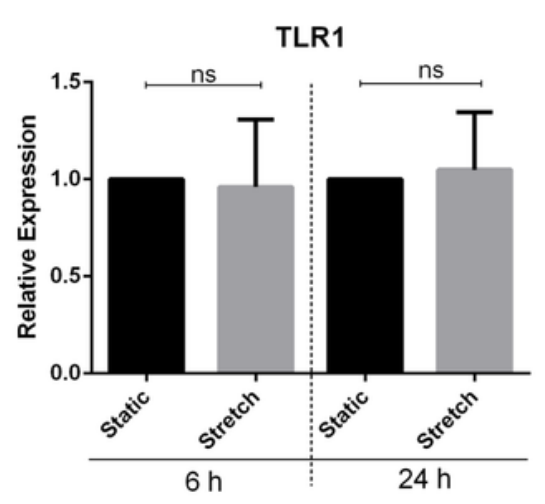

D.

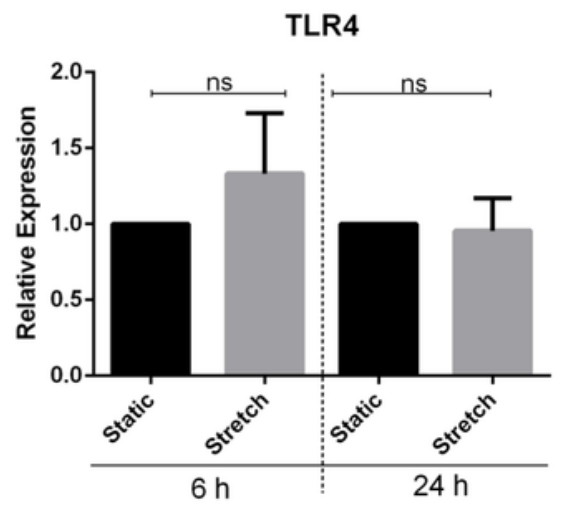

E.
B.
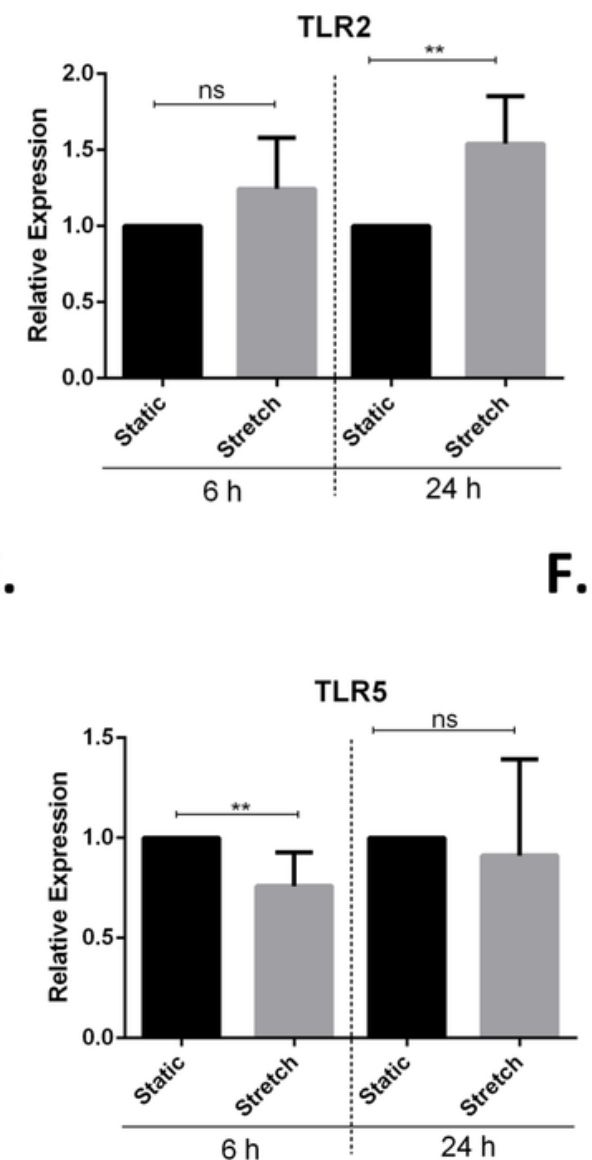

C.

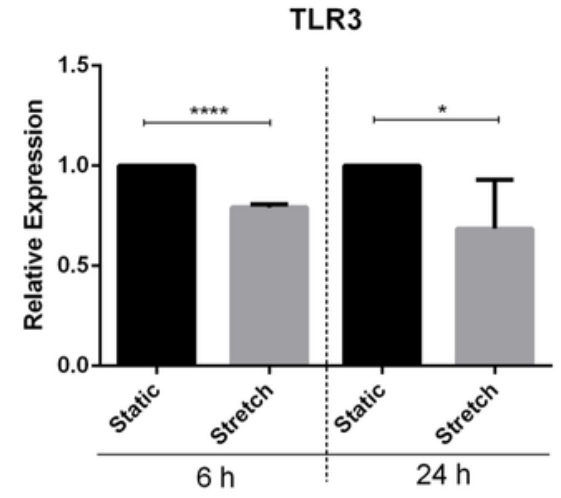

$\mathbf{F}$.

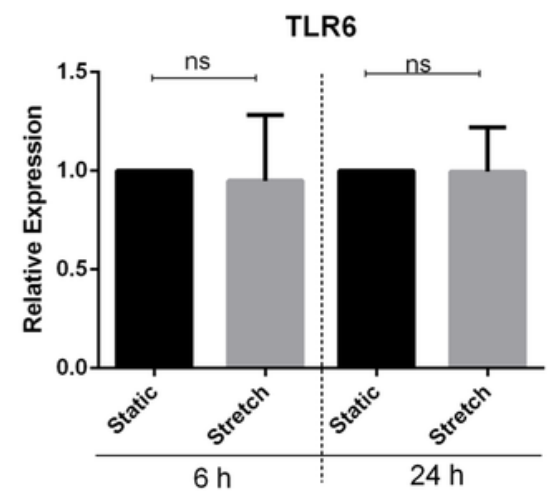

G.

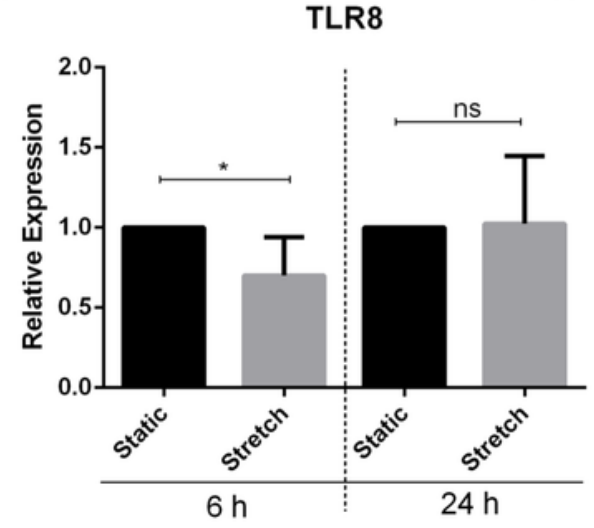

TLR9

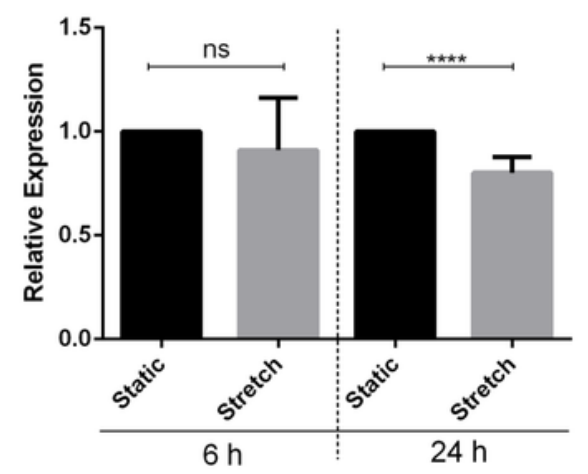




\section{5}

Figure 5: Treatment with 1,25D3 and PBA differentially affects stretch mediated changes in pro-inflammatory cytokine IL-8 gene expression.

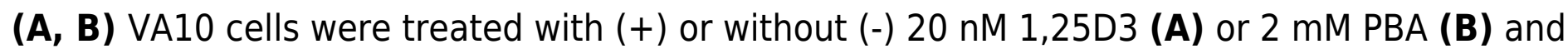
subjected to cyclic stretch for $6 \mathrm{~h}$ and $24 \mathrm{~h}$. The mRNA expression of genes encoding proinflammatory cytokine IL-8 was analyzed with q-RT PCR $(n=3$, mean \pm S.E.). Relative expression levels (y-axis) in static cells were defined with an arbitrary value of ' 1 ' and changes relative to this value in stretched/treated samples are represented. (ns indicates non-significant; $\mathrm{p}<0.05=* ; \mathrm{p}<0.01=* * ; \mathrm{p}<0.0001=* * *)$.

A.

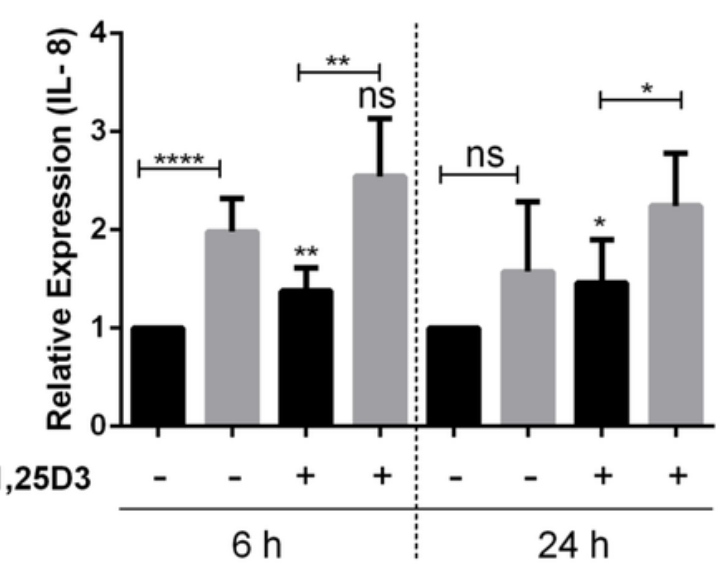

B.

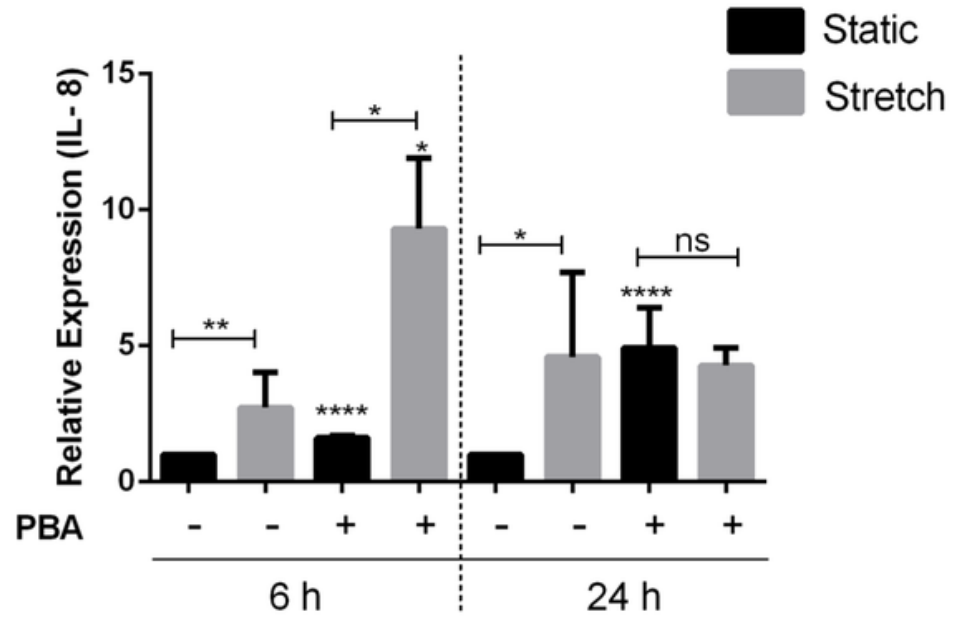


Table $\mathbf{1}$ (on next page)

Primers used in the q-RT PCR assay. 
1 Table 1: Primers used in the q-RT PCR assay.

2

\begin{tabular}{|c|c|c|c|c|}
\hline Primer & $\begin{array}{l}\text { Gene } \\
\text { Symbol }\end{array}$ & $\begin{array}{l}\text { Ref. Seq. } \\
\text { Number }\end{array}$ & Forward Primer & Reverse Primer \\
\hline CAMP & $C A M P$ & NM_004345 & $\begin{array}{l}\text { 5'-GCA GTC ACC AGA } \\
\text { GGA TTG TGA C-3' }\end{array}$ & 5'-CAC CGC TTC ACC AGC CC-3' \\
\hline DEFB1 & $D E F B 1$ & NM_005218 & $\begin{array}{l}\text { 5'-CCA GTC GCC ATG } \\
\text { AGA ACT CC-3' }\end{array}$ & $\begin{array}{l}\text { 5'-GTG AGA AAG TTA CCA CCT } \\
\text { GAG GC-3' }\end{array}$ \\
\hline IL-8 & CXCL8 & NM_000584 & $\begin{array}{l}\text { 5'-CTG GCA TCT TCA } \\
\text { CTG ATT CTT G-3' }\end{array}$ & $\begin{array}{l}\text { 5'-TGT CTG GAC CCC AAG } \\
\text { GAA-3' }\end{array}$ \\
\hline IP-10 & CXCL10 & NM_001565 & $\begin{array}{l}\text { 5'-CAG TTC TAG AGA } \\
\text { GAG GTA CTC CT-3' }\end{array}$ & $\begin{array}{l}\text { 5'-GAC ATA TTC TGA GCC TAC } \\
\text { AGC A-3' }\end{array}$ \\
\hline RANTES & CCL5 & NM_002985 & $\begin{array}{l}\text { 5'-TGC CAC TGG TGT } \\
\text { AGA AAT ACT C-3' }\end{array}$ & $\begin{array}{l}\text { 5'-GCT GTC ATC CTC ATT GCT } \\
\text { ACT-3' }\end{array}$ \\
\hline IL-1及 & $I L 1 B$ & NM_000576 & $\begin{array}{l}\text { 5'-GAA CAA GTC ATC } \\
\text { CTC ATT GCC-3' }\end{array}$ & $\begin{array}{l}\text { 5'-CAG CCA ATC TTC ATT GCT } \\
\text { CAA G-3' }\end{array}$ \\
\hline PPIA & PPIA & NM_021130 & $\begin{array}{l}\text { 5'-TCT TTC ACT TTG } \\
\text { CCA AAC ACC-3' }\end{array}$ & $\begin{array}{l}\text { 5'-CAT CCT AAA GCA TAC GGG } \\
\text { TCC-3' }\end{array}$ \\
\hline TLR1 & TLR1 & NM_003263 & $\begin{array}{l}\text { 5'-CAA GAC TGT AGC } \\
\text { AAA TCT-3' }\end{array}$ & $\begin{array}{l}\text { 5'-GTT TCG CCA GAA TAC TTA- } \\
3 \text {, }\end{array}$ \\
\hline TLR2 & $T L R 2$ & NM_003264 & $\begin{array}{l}\text { 5'-ATG ACC CCC AAG } \\
\text { ACC CA-3' }\end{array}$ & $\begin{array}{l}\text { 5'-CCA TTG CTC TTT CAC TGC } \\
\text { TTT C-3' }\end{array}$ \\
\hline TLR3 & $T L R 3$ & NM_003265 & $\begin{array}{l}\text { 5'-GCA CTG TCT TTG } \\
\text { CAA GAT GA-3' }\end{array}$ & $\begin{array}{l}\text { 5'-AGA CCC ATA CCA ACA TCC } \\
\text { CT }-3 \text { ' }\end{array}$ \\
\hline TLR4 & TLR4 & NM_003266 & $\begin{array}{l}\text { 5'-ACC CCA TTA ATT } \\
\text { CCA GAC ACA-3' }\end{array}$ & $\begin{array}{l}\text { 5'-GAG TAT ACA TTG CTG TTT } \\
\text { CCT GTT G-3' }\end{array}$ \\
\hline TLR6 & TLR6 & NM_006068 & $\begin{array}{l}\text { 5'-TAT CCT ATC CTA } \\
\text { TTG-3' }\end{array}$ & $\begin{array}{l}\text { 5'-AGT TGC CAA ATT CCT TAC- } \\
3 \text { ', }\end{array}$ \\
\hline
\end{tabular}




\begin{tabular}{|l|l|l|l|l|}
\hline TLR8 & TLR8 & NM_138636 & $\begin{array}{l}\text { 5'-GAT CCA GCA CCT } \\
\text { TCA GAT GAG-3' }\end{array}$ & $\begin{array}{l}\text { 5'-ACT TGA CCC AAC TTC GAT } \\
\text { ACC-3' }\end{array}$ \\
\hline TLR9 & TLR9 & NM_017442 & $\begin{array}{l}\text { 5'-GGA GCT CAC AGG } \\
\text { GTA GGA A-3' }\end{array}$ & $\begin{array}{l}\text { 5'-AGA CCC TCT GGA GAA } \\
\text { GCC-3' }\end{array}$ \\
\hline UBC & UBC & NM_021009 & $\begin{array}{l}\text { 5'-GAT TTG GGT CGC } \\
\text { AGT TCT TG-3' }\end{array}$ & $\begin{array}{l}\text { 5'-CCT TAT CTT GGA TCT TTG } \\
\text { CCT TG-3' }\end{array}$ \\
\hline LZY & LZY & NM_000239 & $\begin{array}{l}\text { 5'-CTC CAC AAC CTT } \\
\text { GAA CAT ACT GA-3' }\end{array}$ & $\begin{array}{l}\text { 5'-AGA TAA CAT CGC TGA TGC } \\
\text { TGT AG-3' }\end{array}$ \\
\hline LTF & LTF & NM_00119914 & $\begin{array}{l}\text { 5'-AAT AGT GAG TTC } \\
\text { GTG GCT GTC-3' }\end{array}$ & $\begin{array}{l}\text { 5'-TGT ATC CAG GCC ATT GCG- } \\
\text { 3' }\end{array}$ \\
\hline & & 9 & & \\
\hline
\end{tabular}

3 